\title{
東北地方太平洋沖地震における 都市ガス導管の被害分析
}

\author{
向後 陽平 1 ・ 丸山 喜久 2 ・猪股 渉 3 \\ 1学生会員 千葉大学博士前期課程 大学院工学研究科（†263-8522 千葉市稲毛区弥生町1-33） \\ E-mail: aana2220@chiba-u.jp \\ 2正会員 千葉大学准教授 大学院工学研究科（†263-8522 千葉市稲毛区弥生町1-33） \\ E-mail: ymaruyam@tu.chiba-u.ac.jp \\ 3正会員 東京ガス株式会社 防災・供給部（干105-8517 東京都港区海岸1-5-20） \\ E-mail: inomataw@tokyo-gas.co.jp
}

\begin{abstract}
2011年東北地方太平洋沖地震では，東京ガス（株）の供給エリアで而震性の劣る低圧ガス導管に被害が 発生した。防災システムSUPREMEが確実に稼働したことで安全を確保するとともに，この地震に関する 多くのデータを得た。SUPREMEの被害推定式は，ネジ継手を有する本支管に対して精度が高いことが既 往研究によって確認された。一方, 供給管や灯外内管に関しては, SI值と被害率の関係性がやや異なって いた。そこで，本研究では，供給管の被害率とSI值との関係性を評価し，被害予測式を構築する。さらに， 本支管の被害を継手ごとに整理し，被害予測式の地形補正係数に関する評価を行い，被害推定の高度化を 図る.
\end{abstract}

Key Words :The 2011 off the Pacific Coast of Tohoku Earthquake, SUPREME, damage to gas distribution pipes, fragility curve

\section{1. はじめに}

2011年東北地方太平洋沖地震では，水道，ガスなどの 埋設管に多くの被害が発生した．東京ガス（株）の供給 エリアでは, 而震性の劣る低厓ス導管に被害が発生し たが，防災システムSUPREME ${ }^{1-3)}$ が確実に稼働し安全を 確保した。低圧ガス導管における被害数 ${ }^{4}$ を表-1にまと める. なお，都市ガスの設備区分は図-1に示寸通りであ る. SUPREMEによって, 供給エリア内に設置されてい る約4000箇所のSIセンサーなどから，この地震に関する 多くのデータを得ることができた.

既往研究4)では, 東北地方太平洋沖地震の際に被害の 大半を占めたネジ継手の本支管被害率について, SUPREMEに搭載されている被害推定式の精度検証が行 われた．本支管のネジ継手に関してはSUPREMEの被害 推定式の精度が高いことが確認できたが，供給管や灯外 内管のネジ継手に関してはSI值と被害率の関係性が本支 管のネジ継手とやや異なっていることが分かった.

そこで本研究では, ネジ継手の供給管, 灯外内管 (埋 設部）に関して, 東北地方太平洋沖地震の際の被害分析 を行う。被害率とSI值の関係性を評価し, 被害予測式を 構築する.さらに，本支管の被害を継手ごとに整理し，
表-1 東北地方太平洋沖地震における東京ガス供給エリア の低圧導管の被害数 ${ }^{4}$

\begin{tabular}{|c|c|c|c|c|c|c|c|c|}
\hline & \multicolumn{6}{|c|}{ 埋設部 } & \multirow{2}{*}{ 地上部 } & \multirow{2}{*}{ 合計 } \\
\hline & 接合部 & \multicolumn{5}{|c|}{ 管体 } & & \\
\hline \multirow{2}{*}{ 本支管 } & \multirow{2}{*}{72} & 亀裂 & 折損 & 水溜まり & 接合部孪間 & $\begin{array}{l}\text { 経年 } \\
\text { 㸓化 }\end{array}$ & \multirow{2}{*}{ - } & \multirow{2}{*}{145} \\
\hline & & 10 & 3 & 4 & 1 & 55 & & \\
\hline 供給管 & 23 & \multicolumn{5}{|c|}{108} & - & 131 \\
\hline 灯外内管 & 137 & \multicolumn{5}{|c|}{372} & 420 & 929 \\
\hline
\end{tabular}

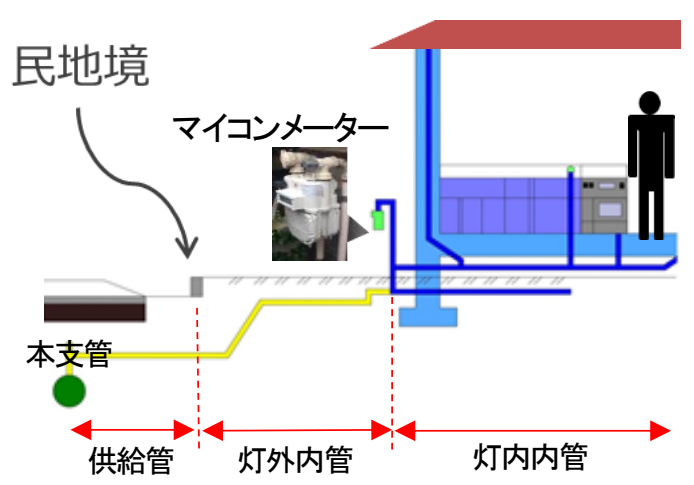

図-1＼cjkstart都市ガス供給の設備区分 
被害予測式の地形補正係数を導出し，被害予測の高度化 を図る.

\section{2. 分析対象データ}

本研究では，東京ガス（株）がとりまとめた東北地方 太平洋沖地震の際のガス管の被害データ, $50 \mathrm{mメッシュ}$ ごとの管路延長データ，SUPREMEによって推定された 50 mメッシュのSI值分布（図-2），PL值分布（図-3）を 用いた．なお，図-2には設備区分ごとのガス導管の被害 位置も併せて示している. 地形区分は，東京ガス（株） が定めている地形区分 ${ }^{1)}$ (50 mメッシュ) を使用した

\section{(図-4).}

ガス管の被害は，被害位置，設備区分（本支管，供給 管，灯外内管など），管種，接合方法が取りまとめられ ている．また，管種，接合方法ごとにガス導管の延長が

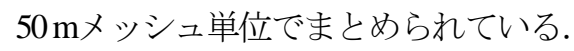

\section{3. 供給管 - 灯外内管（埋設部）の被害分析}

\section{（1）被害率の算出}

地理情報システム（GIS）を用いて，ガス管の被害デ ータと50 mメッシュごとの管路延長データに，SI值分布， PL值分布のデータを結合した。 ネジ継手の供給管, 灯 外内管（埋設部）の被害数と管路延長のデータをSI值1 $\mathrm{cm} / \mathrm{s}$ ごとに集計し，被害率を算出した．被害率は，管路 1 kmあたりの被害数で定義している12,5).さらに, PL值 5.0以上のメッシュで液状化が発生しているものと仮定の, ${ }^{7}$ ᄂ, 非液状化地域のみを対象に被害率を算出した（図一 5）。なお，液状化地域では，ネジ継手を有する供給管 では5件の被害が発生し，その延長は7 km, 被害率 0.71 件 /kmである. また，ネジ継手の灯外内管（埋設部）は17 件の被害，延長は $26 \mathrm{~km}$ ，被害率 0.65 件 $/ \mathrm{km}$ である.

ネジ継手の供給管と灯外内管（埋設部）の被害率は, $\mathrm{SI}$ 值が $10 \mathrm{~cm} / \mathrm{s}$ 程度のときおよそ0.1件/ $\mathrm{km}$ を示しており， ネジ継手の本支管の被害率よりも大きい. SI值が約40 $\mathrm{cm} / \mathrm{s}$ 以上になると被害率は0になるが，これは今回のデ ータでは, SI值が $40 \mathrm{~cm} / \mathrm{s}$ 以上の地震動を受けた管路延長 が短いためである. 今後は別の地震の際の被害データを 参照するなどして，SI值が大きい場合の被害率の信頼性 を高める必要がある．また，供給管と灯外内管（埋設部） の被害率は，SI值に対してあまり大きな違いは見られな かった。 これは供給管と灯外内管には, 埋設深さや配管 系, 管材質などに若干の違いはあるものの, 被害の要因 となる継手の基本的構造が同じであるためと考えられる (図-1）。そこで, 本研究では供給管と灯外内管（埋設
部）の被害率は区別せず，まとめて被害予測式を構築す る.

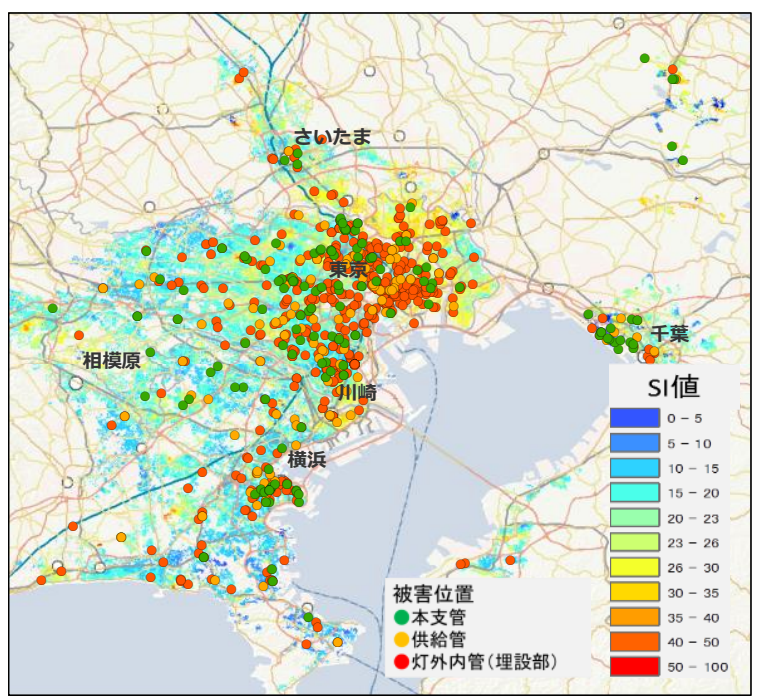

図-2 50mメッシュごとの SI值分布とガス導管被害位置

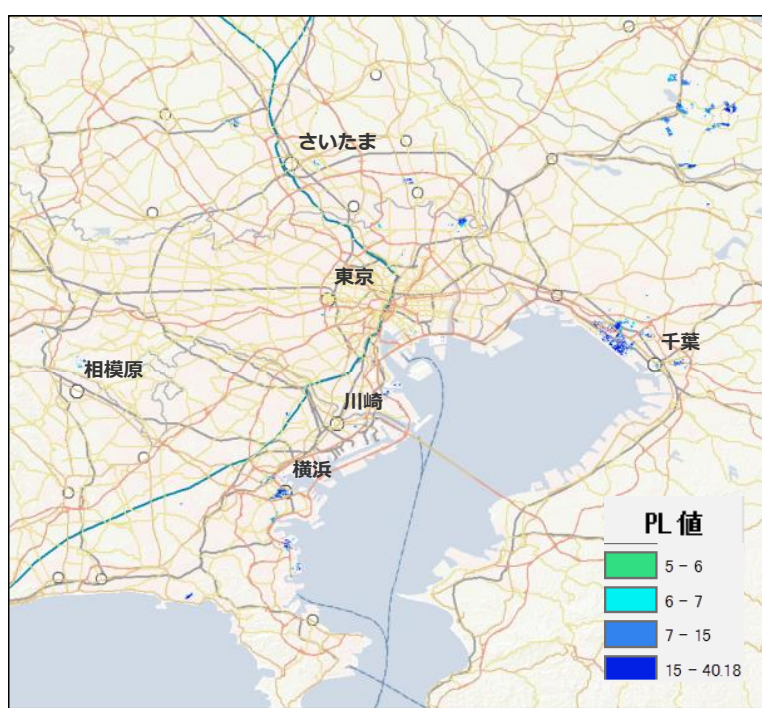

図-3 50m メッシュごとのPL值分布図

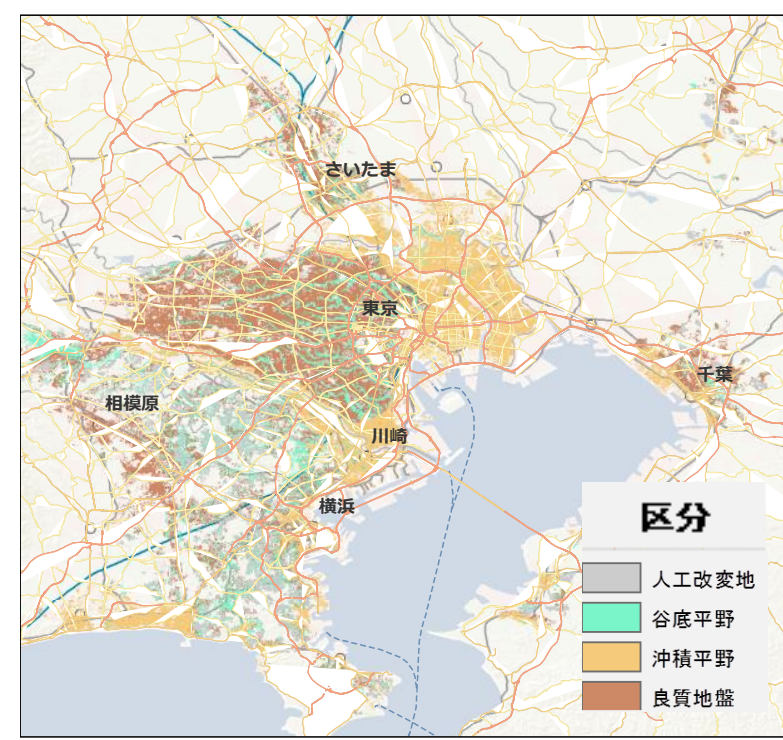

図-4 50m メッシュごとの地形区分 


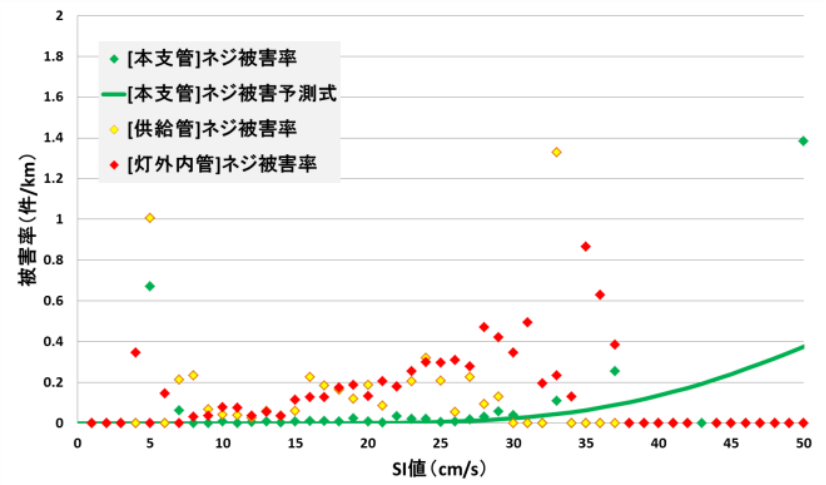

図-5＼cjkstart非液状化地域におけるネジ継手のガス導管の被害率 と SI值の関係

\section{（2）被害予測式の構築}

ネジ継手を有する供給管，灯外内管（埋設部）の被害 予測式は，SUPREMEが搭載している本支管 (ネジ継手) の被害予測式を変形し構築した. 本支管の被害予測式の 関数形は式(1)のようであるが，このうちパラメータ入を 管路延長 $w$ を重みとした誤差の2乗和 $\varepsilon$ を最小化するよう に定めた（式(2) ${ }^{8999}$.

$$
\begin{aligned}
P & =C \Phi((\ln S I-\lambda) / \zeta) \\
\varepsilon & =\sum\left(P_{R}-P\right)^{2} w
\end{aligned}
$$

ここで，被害率 $P$ は，SI值に関する対数正規分布に倍率 Cが乗じられた関数形で表されている． 分布の確率分布関数を表す．なお，本支管 (ネジ継手)

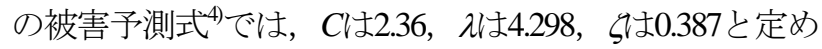
られている，また， $P_{R}$ は実被害率を表す。

本研究では，式(1)の $C ， \zeta ， \lambda の う ち ， \lambda の$ 从を回帰分 析によって定めた．式(1)の入を変化させることによって， 曲線がln SIに対して平行移動する. 本研究で扱った供給 管および灯外内管（埋設部）の被害データは，SI值が概 衫 $50 \mathrm{~cm} / \mathrm{s}$ 以下の範囲である.ネジ継手の本支管の被害関 数のもととなっている兵庫県南部地震の $\mathrm{SI}$ 值と比べ, SI 值が小さくレンジも大きくない.このため，被害率の上 限を表すCは，このデータセットだけを用いた回帰分析 で求めることがあまり適当でないものと判断した．さら に, SIの変動係数に関係するらは本支管の被害関数（式 (1)）と等しいものと仮定した． $P_{R}$ に供給管，灯外内管 （埋設部）について算出した被害率を代入したところ， 式(2)のをを最小にするגは3.73となった。構築したネジ継 手を有する供給管と灯外内管（埋設部）の被害予測式と 実際の被害率を比較したものを図一6に示す。

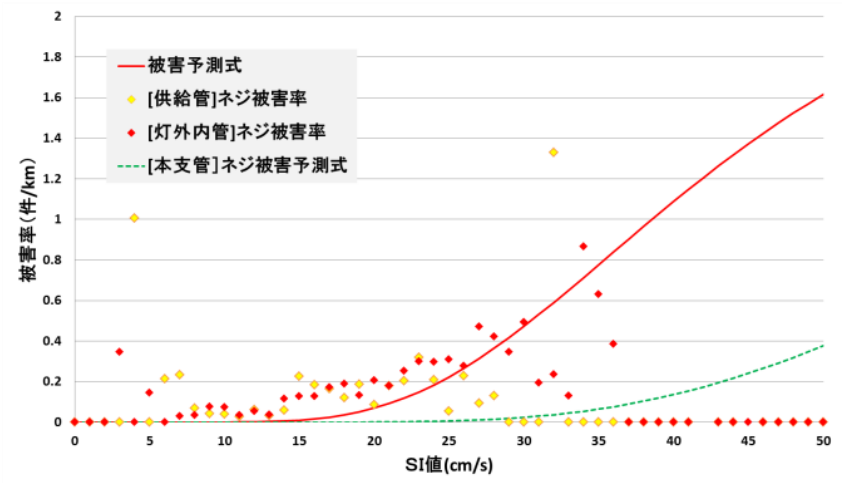

図-6 ネジ継手の供給管，灯外内管（埋設部）の被害予測式

\section{4. 本支管の地形区分ごとの被害分析}

\section{（1）地形補正係数に関する検討}

本章では，被害予測の高度化を目指し，非液状化地域 の本支管のうち耐震性の低いネジ継手，機械式継手とし て初期に採用されていたLM継手の被害を地形区分ごと に分析する.メッシュごとの被害数をポアソン過程を仮 定して推定し, 東北地方太平洋沖地震の際の実測值と比 較を行う。この成果は，ガス導管の被害予測式に導入さ れている補正係数の再検討や継手別のガス導管の耐震性 能評価に貢献できる，なお，本章では，地震動による被 害を峳密に評価することを目的としている，そこで，ガ 又導管の被害のうち管体の経年劣化が主因と考えられる 被害は除外した（表-1参照）。

ガス導管の被害の発生が，ポアソン過程に従うものと 仮定する ${ }^{10,11)}$ ．このとき，メッシュごとの被害数は，以 下のように書ける.

$$
p\left(X=x_{k}\right)=\left(N_{c k}\right)^{x_{k}} \cdot \exp \left(-N_{c k}\right) / x_{k} ! \quad\left(x_{k}=0,1,2, \cdots\right)
$$

ここで, $k$ はメッシュコード, $p\left(X=x_{k}\right)$ はメッシュ内の被 害数が $x_{k}$ である確率を表す． $N_{c k}$ はメッシュごとの平均被 害数であり, 以下のように仮定した.

$$
N_{c k}=2.36 \Phi\left(\left(\ln S I_{k}-4.298\right) / 0.387\right) \times C^{\prime} \times l_{k}
$$

すなわち，ネジ継手の本支管の被害関数を基準とした被 害率に，メッシュごとの管路延長 $l_{k}$ を乗じている．さら に，地形区分（図-4）ごとの補正係数（地形補正係数） としてC’を導入している.SSI $I_{k}$ はメッシュごとのSI值を表 

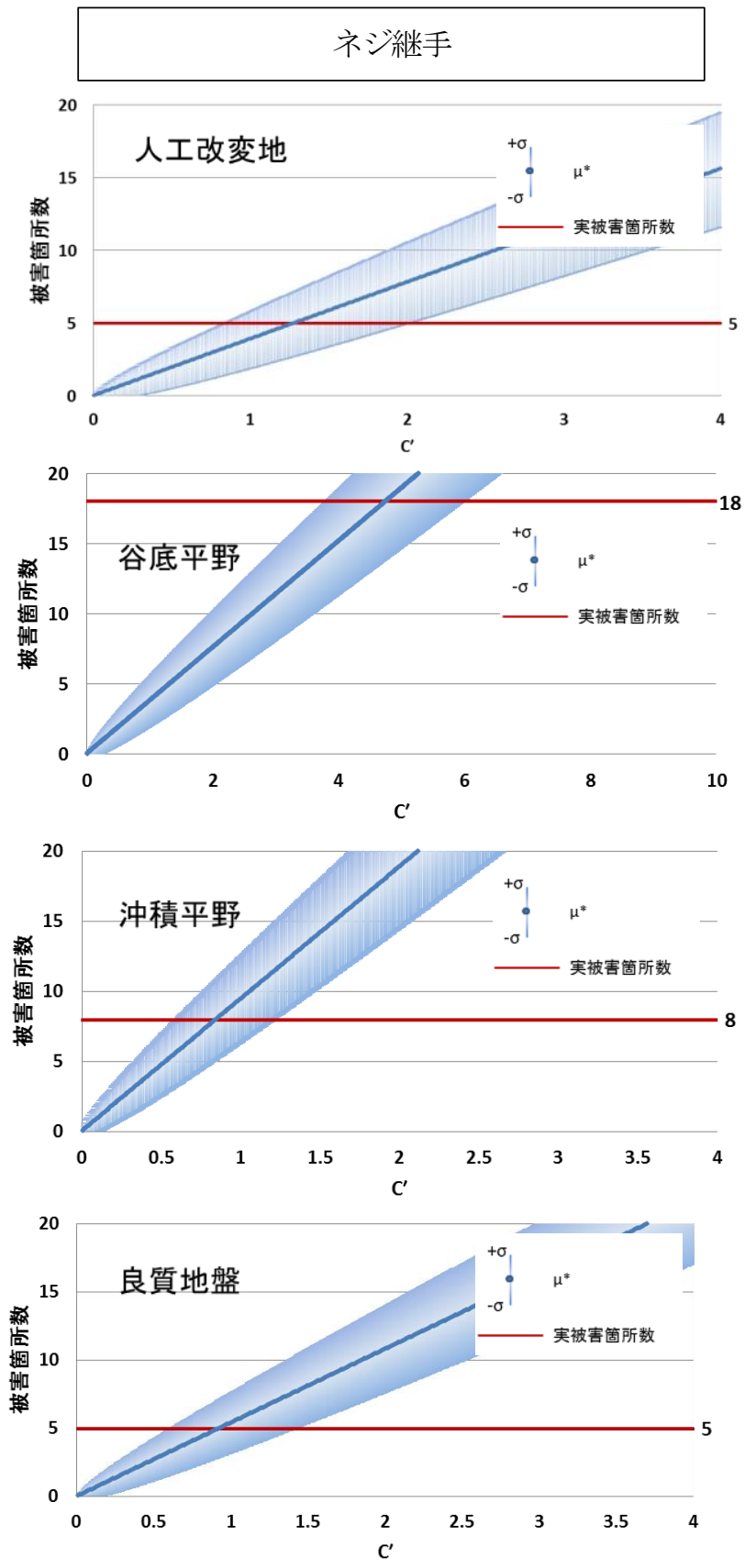
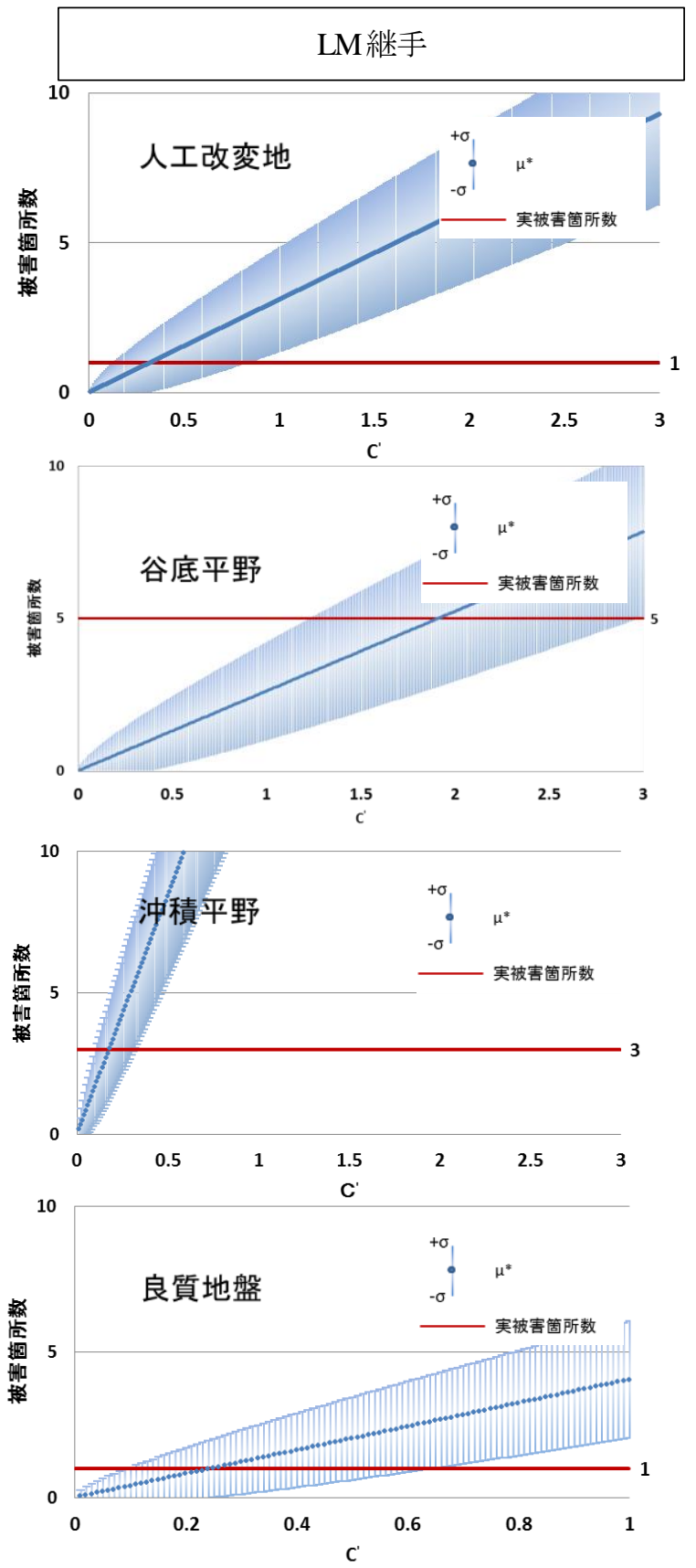

図-7 非液状化地域における本支管（ネジ継手およびLM継手）の地形区分ごとの補正係数の評価

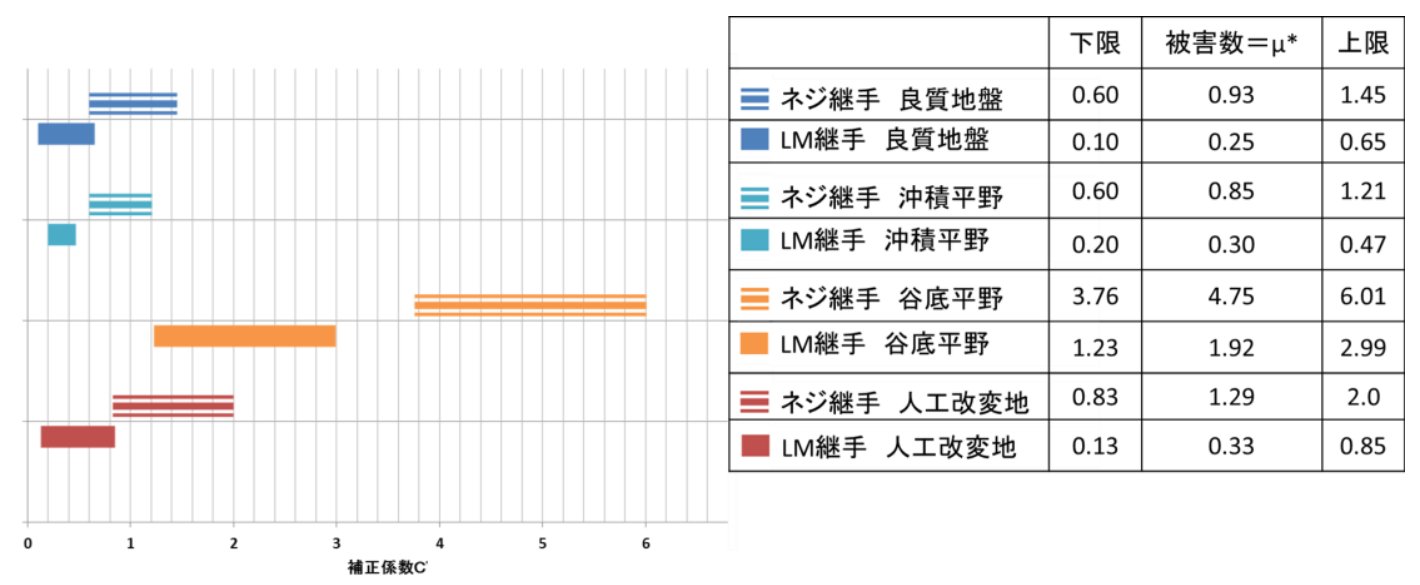

図-8＼cjkstart地形区分ごとの補正係数（本支管ネジ継手およびLM継手） 
寸. 補正係数 C’の值を適宜変化させ, 式(3), (4)に従う平 均被害数をメッシュごとの被害数とみなした。この結果 と東北地方太平洋沖地震の際のガス導管の被害数を比較 し，地形補正係数に関する検討を行う.

独立な確率変数 $X, Y$ 多それぞれ平均值 $\lambda_{1}, \lambda_{2}$ のポアソ ン分布 $p\left(\lambda_{1}\right), p\left(\lambda_{2}\right)$ に従っているとき, 確率変数の和 $X+$ $Y$ はポアソン分布 $p\left(\lambda_{1}+\lambda_{2}\right)$ に従う（ポアソン分布の再生性） 12).式(3)，(4)のようにメッシュごとのガス導管の被害の 発生がポアソン過程に従うとき，ある地形区分の被害総 数は, ある地形補正係数 $C^{\prime}$ の下で式(5)のように算出さ れる $\mu$ をを平均值とするポアソン分布に従う。

$$
\mu^{*}=\sum_{k=1} N_{c k}
$$

またこのときの標準偏差は式(6)のようになる.

$$
\sigma=\sqrt{\mu^{*}}
$$

図-7に, 地形補正係数 $C^{\prime}$ と地形区分ごとの推定被害数の

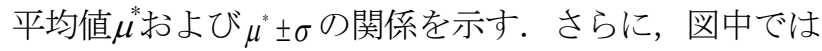
東北地方太平洋沖地震の際の実際の被害数を併せて示し ている，たとえば，ネシ継手の本支管では，人工改変地 で地震動が主因と考えられる接合部および管体の亀裂, 折損の被害が5件発生している。この被害数は，地形補 正係数C’を $0.83 \sim 2.0$ とすると, $\mu^{*} \pm \sigma$ の範囲で再現でき る.

図一のように推定された，ネジ継手およびLM継手の本

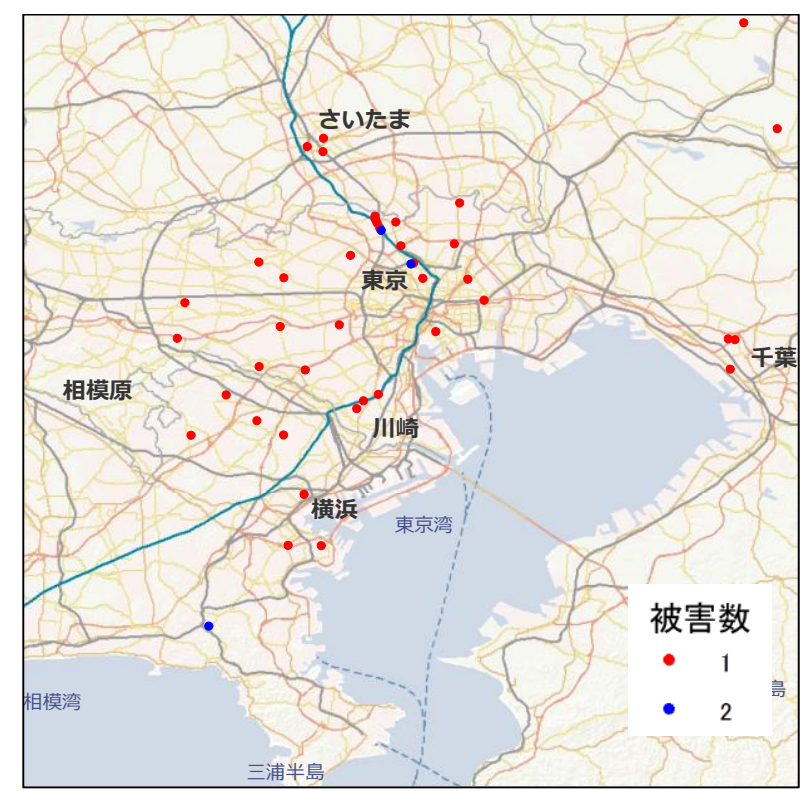

非液状化地域の実被害箇所

（被害箇所数 : 46 箇所）
支管の地形区分に応じた補正係数の範囲をに示す．平均 的には, ネジ継手の補正係数は沖積平野, 良質地盤, 人 工改変地の順に大きくなるが，顕著な違いはない，一方， 谷底平野の補正係数はほかの3つの地形区分と比べて大 きく，例えば沖積平野に対して約 5 ６倍の補正係数を示 している．地盤の不整形性の影響によって，地震動が増 幅されたり，ひずみが不整形境界面で大きくなる め，とくに谷底平野で埋設管に被害が生じやすかったも のと考えられる. LM継手はネジ継手と比べ，どの地形 区分においても補正係数が小さいことが分かる．具体的 には，沖積平野のLM継手の補正係数はネジ継手のもの の約0.4倍程度である.

\section{（2）被害推定結果と実被害の比較}

前項で得た補正係数を用いて，地形区分ごとに被害予 測を行った. 図-8に示した実被害数とポアソン分布の平 均值 $\mu$ が一致するときの地形補正係数を各地形区分の補 正係数と仮定し,メッシュごとに被害数を推定した. 具 体的には, 式(3)に従うポアソン乱数を各メッシュ1回だ け発生させた. ネジ継手の本支管について推定された被 害数は，人工改変地で6件，谷底平野で17件，沖積平野 で6件，良質地盤で5件の合計34件となった．実被害数は 人工改変地で5件, 谷底平野で18件, 沖積平野で8件, 良 質地盤で5件の合計36件であった。 またLM継手に関して は，人工改変地で0件，谷底平野で5件，沖積平野で3件， 良質地盤で0件の合計8件が推定された。実被害は人工改 変地で1件, 谷底平野で5件, 沖積平野で3件, 良質地盤 で1件の合計10件であった。

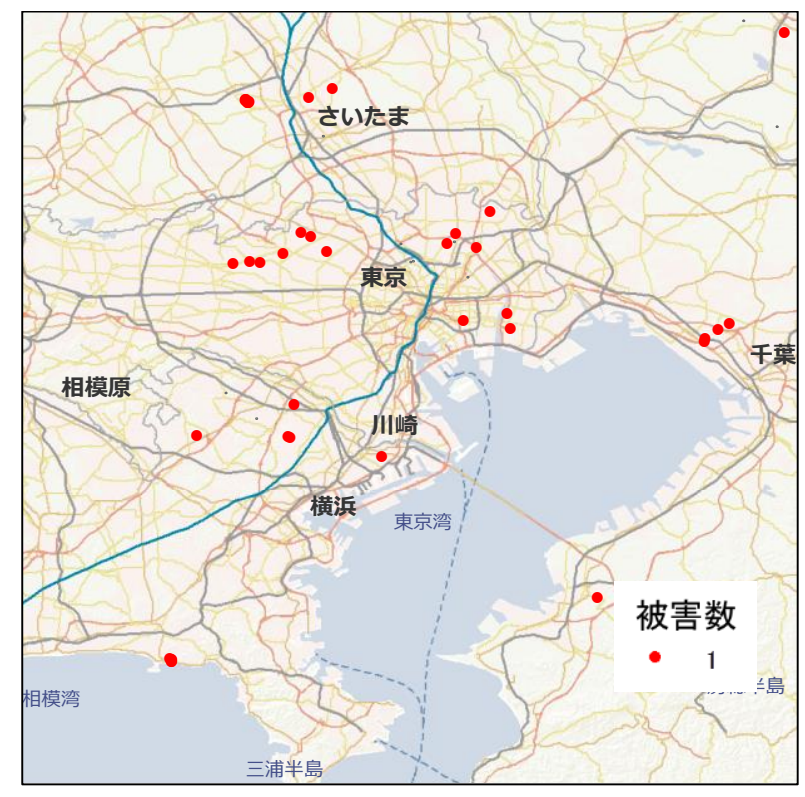

非液状化地域の推定被害箇所

（被害箇所数：42 箅所）

図-9＼cjkstart実被害箇所と推定された被害箇所の比較（本支管ネジ継手およびLM継手） 
図-9は，被害推定結果と実被害の位置を比較したもの である．罒中では，ネジ継手およびLM継手の本支管の 被害数を示している．被害が発生していると推定された メッシュの位置が実被害と厳密に一致したメッシュはな かった．補正係数を調整することによって被害総数の推 定精度を高めることはできたが，被害位置を的中させる ことには至らなかった。

\section{5. まとめ}

本研究では，東北地方太平洋沖地震において被害が 多かったネジ継手の供給管，灯外内管に関して，SI值と 被害率の関係性を評価した. さらに回帰分析を行うこと で被害予測式を構築した。 また，本支管のネジ継手およ びLM継手を対象として，被害予測式の地形補正係数に 関する検討を行った。

今後は，液状化地域でのSI值と被害率の関係性を評価 する. さらに，供給管や灯外内管の継手別，地形別の地 震時脆弱性評価を行う予定である.

\section{参考文献}

1）清水善久, 石田栄介, 磯山龍二, 山崎文雄，小金丸健一, 中山渉 : 都市ガス供給網のリアルタイム地震防災システ ム構築及び広域地盤情報の整備と分析・活用，土木学会 論文集, No. 738/I-64,pp.283-296, 2003.

2) 東京ガス：超高密度リアルタイム地震防災システム 「SUPREME」， http://www.tokyo-gas.co.jp/techno/stp3/97c1 j.html（2015 年 8 月 24 日閲覧）.

3) 東京ガス：ガバナに関して，http://www.tokyo-gas.co.jp/ encyclopedia/dictionary/dictionary40.php（2015 年 8 月 24 日閲 覽）.

4）猪股渉，乗藤雄基，石田栄介，塚本博之，山崎文雄 : 東
日本大震災における東京ガスの設備被害の概況と超高密 度観測情報に基づく低圧ガス導管被害推定の精度検証, 日本地震工学会論文集, Vol. 13, No.2, pp.37-44， 2013.

5）丸山喜久，伊藤智大，若松加寿江，永田茂 : 東北地方太 平洋沖地震における宮城県仙台市の水道管路被害状況の 分析，土木学会論文集 A1（構造・地震工学）, Vol. 70, No. 3,pp. 377-388, 2014.

6) 石田栄介, 未富岩雄, 安田進, 細川直行 : リアルタイム 地震防災システムにおける液状化危険度分布の即時推定 法の提案, 土木学会論文集 A1 (構造・地震工学) , Vol. 65, No. 1,pp. 596-605, 2009.

7）（社）日本ガス協会：高圧ガス導管液状化耐震設計 指針，2001。

8) 丸山喜久, 山崎文雄, 用害比呂之, 土屋良之 : 新潟県中 越地震の被害データに基づく高速道路盛土の被害率と地 震動強さの関係，土木学会論文集 A, Vol. 64, No.2, pp. 208-216, 2008.

9）神足史人：Excel で操る！ここまでできる科学技術計算, 丸善, 2009.

10) Federal Emergency Management Agency: Hazus-MH 2.1 Technical Manual, 2015.

11）永田茂，丸山喜久，庄司学：既往の上水道配水管の 地震被害予測式の予測精度に関する検討, 土木学会 論文集 A1（構造・地震工学）, Vol. 71, No. 4, pp. I_50-I_61, 2015.

12) 浅見泰司: 都市工学の数理 : 基礎編, 日本評論社, 2015.

13）清野純史, 井上佳樹, 清水謙司：地震時における埋 設管に及ぼす不整形地盤の影響について, 土木学会 論文集 A1（構造・地震工学）, Vol. 65, No. 1, pp. 214-221, 2009.

14) Ichimura, T., Fujita, K., Hori, M., Sakanoue, T. and Hamanaka, R.: Three-dimensional nonlinear seismic ground response analysis of local site effects for estimating seismic behavior of buried pipelines, Journal of Pressure Vessel Technology, ASME, DOI: 10.1115/1.4026208, 2014.

(2015. 11.3受付, 2016.1.27修正, 2016.2. 20受理)

\title{
DAMAGE TO GAS DISTRIBUTION PIPES IN TOKYO METROPOLITAN AREA AFTER THE 2011 GREAT EAST JAPAN EARTHQUAKE
}

\author{
Yohei KOGO, Yoshihisa MARUYAMA and Wataru INOMATA
}

This study investigates the damage ratios of gas distribution pipelines in Tokyo Metropolitan area after the 2011 off the Pacific coast of Tohoku earthquake. The relationship between the damage ratios and spectrum intensities (SI), which were observed by a real-time earthquake monitoring system, SUPREME, operated by Tokyo Gas Co., Ltd., is evaluated. A fragility function for gas supply pipes is newly developed by this study. The effects of topographical conditions on the damage situations of gas distribution pipelines are also investigated. More damage incidents to gas pipes are expected in the valley bottom lowland. 